\title{
On Going Organizing: Black August Organizing Committee
}

Mission Statement:

The Black August Organizing Committee is a community-based organization, which has been in existence for 25 years. Our goals include: Working to free Political Prisoners, Prisoners of War and Prisoners of Conscious, many of whom have been locked away for 10, 20, 30 and 40 years with no end in sight. Working to shut down the sensory deprivation torture chambers known publicly as Security Housing Units or SHU programs. Working to maintain a community awareness of and involvement in the legal, medical and social issues affecting prisoners in general and politically conscious prisoners in particular. Working to provide alternatives for our youth in the streets to being caught up in the prison industrial complex.

As an organization, we began working in the community on issues directly affecting people's lives, such as: police brutality, food programs, housing aid and legal assistance. To this day we have worked to be of service to the community in as many ways as we can. Our programs are people oriented and strive to educate and uplift. Our dedication is to those Freedom Fighters still in the concentration camps after decades of incarceration, as well as to the youth of our communities who are in grave danger of joining them, or dying in the streets.

Black August Organizing Committee

1714 Franklin St. \#100-309

Oakland, CA 94612

510-658-7079

originalbaoc@dragonspeaks.org

www.dragonspeaks.org 